\title{
Convertibility of Capital Account: A Comparative Analysis
}

\author{
Md. Ariful Islam (Corresponding author) \\ Deputy Manager, BASIC Bank Limited \\ Khulna Branch, 107 Sir Iqbal Road, Khulna, Bangladesh \\ Tel: 880-171-752-9503 E-mail: arifrussell@yahoo.com
}

Md. Rayhan Islam

Business Administration Discipline

Khulna University, Khulna, Bangladesh

Tel: 880-171-333-1982 E-mail: rayhan_07@gmail.com

\section{Mahmudul Hasan Siddiqui}

Senior Territory Manager, Unilever Bangladesh Limited

M.N. Trading \& Co, Modina Tower, Habibpur, Narayanganj, Bangladesh

Tel: 880-171-168-8592 E-mail: mhs.sadi@gmail.com

\section{Luthful Karim}

Assistant Manager, BASIC Bank Limited

Khulna Branch, 107 Sir Iqbal Road, Khulna, Bangladesh

Tel: 880-191-212-5098 E-mail: shajiblks@gmail.com

Received: December 14, 2013 Accepted: December 28, 2013

doi:10.5296/ber.v4i1.4711 URL: http://dx.doi.org/10.5296/ber.v4i1.4711

\begin{abstract}
Convertibility of capital account - the complete elimination of all capital controls - was often treated in the 1990s as an integral element of the market liberalization that was being urged on emerging markets. In the middle of the decade there was even talk of making it an objective of
\end{abstract}


international policy that would be embodied (as a long-term target) in the IMF Articles. This study attempts to focus on issues and experiences of other countries regarding capital account convertibility and figures out lessons for Bangladesh. Fischer (1998, p.2) wrote, "capital account liberalization is an inevitable step on the path of international development, which cannot be avoided and should be embraced. After all, the most advanced economies have open capital accounts." Until the Asian Crisis, discussion of capital account convertibility focused on sequencing issues, and speed. In the aftermath of the crisis, the emphasis has shifted to caution regarding capital account convertibility. In our country Capital Account is not convertible. However, experiences from Latin America (Mexico, Chile etc.) and very recently from Asia (Indonesia, South Korea, Malaysia, Thailand, Philippine etc.) showed that financial opening involves substantial risks and can be ended in financial crash. A lot of improvement and precautionary measures are required before going for Capital Account convertibility. Bangladesh Taka has been declared convertible on current account transaction since 20th October, 1993 and accordingly on the 11th April, 1994 Bangladesh has been awarded with Article VIII status of International Monetary Fund (IMF) Articles of Agreement. Convertibility of Taka in Current Account has a lot of impacts on Balance of Payment position. Right after the reform measures, exports show an increasing trend at an increasing rate from the year 1994-95 to 1997-98. After the convertibility of Bangladesh Taka in different currencies, the export volume takes a rising trend due to flexibility in exchange rate regulation.

Keywords: Convertibility, Capital account, IMF, Currencies, Export, Import

\section{Introduction}

\subsection{Background of the Study}

The flows of capital - debt, equity, and direct and real estate investment - between one country and others are recorded in the capital account of a country's balance of payment. Outflows include resident's purchases of foreign assets and repayment of foreign loans; inflows include foreigner's investments in home-country residents. Freeing transactions like these from restrictions - that is, allowing capital to flow freely in or out of a country without controls or restrictions - is known as capital account liberalization.

The explosive growth of international financial transactions, capital flows and globalization are the most far reaching economic developments of the late twentieth century. Powerful forces have driven the rapid growth of international capital flows, globalization of trade, and encouraged countries toward economic liberalization. Revolutionary changes in information and communication technologies have transformed the financial services industry worldwide.

Convertibility of currency is heavily related to the globalization process because without making our currency convertible to other foreign currencies, one can not make international trade transaction easily and timely.. Convertibility may be either 'partial' or 'full'. Partial convertibility denotes that the transactions related to current account are to make freely. On the other hand, Full convertibility implies free transaction in both current account and capital account of Balance of Payment (BOP) of a country. Capital account liberalization has contributed to higher investment, faster growth and rising living standards in many countries. 


\section{Macrothink}

Business and Economic Research

ISSN 2162-4860

2014, Vol. 4, No. 1

But it has also been associated with costly financial crises in several cases. This means that liberalization carries risks as well as benefits and has major implications for the policies that governments will find it feasible and desirable to follow.

Bangladesh Taka has been declared convertible on current account transaction since 20th October, 1993 and accordingly on the 11th April, 1994 Bangladesh has been awarded with Article VIII status of International Monetary Fund (IMF) Articles of Agreement. The main reasons behind this step are:

- To attract higher foreign investment;

- To promote export;

- To reduce trade deficit;

- To improve the BOP position, especially the Current Account Balance (CAB)

- To create confidence in the strength of Taka.

\subsection{Objectives of the Study}

The objectives of the study are,

- To analyze and understand the issues and experiences of other countries after implementing capital account convertibility.

- To examine the impact of convertibility of capital account on external sector.

- To examine the feasibility of making the Taka convertible on capital account.

- To put forward some suggestions on the way to country's capital account convertibility.

\subsection{Hypothesis of the Study}

For the purpose of study, the research identifies the following hypothesis:

The rules and policies related to convertibility of Taka have significant impact on capital account convertibility.

\subsection{Methodology of the Study}

The research methodology of the study has been enumerated below:

A. Data Collection: For the purpose of this study, the data that are collected is more or less processed data or secondary data. The data have collected from the various sources like research works of individuals, different publications, journals of IMF, World bank, Bangladesh bank, library sources, web pages of World Bank, IMF, WTO, Bangladesh Bank, etc.

B. Treatment of the Data: For understanding the effect of capital account convertibility in different countries, data have been analyzed to compare the financial condition of the countries before convertibility and after convertibility. To understand the 
feasibility of introducing capital account convertibility of taka in our economy, data have been analyzed to realize recent economic trends and prospects of our economy. The balance of payment has been analyzed on the basis of Bangladesh Bank data. All the data have manipulated by standard computer packages like Excel.

\subsection{Limitations of the Study:}

Any research work needs high degree of involvement regarding collection of information, creation of database, literature review and analysis of data. In this study, I tried my best to collect the related information within the time constraint and then analyzed and compared the data. I faced the following limitations of the study:

- This study did not cover primary and unpublished data.

- It has considered data only from Bangladesh Bank, Bangladesh Statistical Bureau, IMF and World Bank publications.

- Data is taken upto 2004 due to some technical error for getting data.

\section{Conceptual framework of Capital Account Convertibility}

\subsection{Convertibility of Capital Account}

Allowing capital to flow freely in or out of a country without controls or restrictions - is known as capital account Convertibility. The flows of capital - debt, equity, and direct and real estate investment - between one country and others are recorded in the capital account of a country's balance of payment. Outflows include resident's purchases of foreign assets and repayment of foreign loans; inflows include foreigner's investments in home-country residents.

Capital market liberalization is considered as an integral component of the overall liberalization process in developing countries. . In a number of studies (King and Levine 1993) capital account openness is found to have positive impact on the depth and efficiency of the domestic financial system. Today, External private capital has become a very important source of funds for investors even in the developing economies. According to Fisher (1998), financial integration and free capital mobility facilitate a more efficient global allocation of savings and help channel resources into the most productive uses, and thus increasing economic growth and welfare.

\subsection{Reasons for Capital Account Convertibility}

Different countries made their capital account convertible for the following reasons.

a) To make the economy internationally competitive.

b) To integrate the economy with global monetary and fiscal system.

c) To increase investment and economic growth. In form of FDI and portfolio investment.

d) To achieve more stable economic growth. 
e) To gain confidence on local currency.

\subsection{Preconditions of Capital Account Convertibility}

To implement convertibility of capital account successfully, the country should check weather her economic and financial conditions are sound enough to safeguard any unpredicted shock. The following conditions should be fulfilled before going for convertibility in order to achieve benefits from convertibility.

a) Internal financial balance must be established through sound fiscal and monetary policies to avoid excessive inflationary pressures.

b) Monetary policy must be managed in such a way that interest rates and exchange rates are broadly consistent with market conditions.

c) External financial balance must be achieved by setting the exchange rate at a level that would clear the Demand for and supply of foreign exchange.

d) Adequate level of reserves should be maintained to allow a country to absorb domestic and exogenous shocks.

e) Incentives system must be liberalized to allow positive effect on resource allocation.

f) Country should have a sound macro-economic policy framework; in particular monetary and fiscal policies that are consistent with the choice of exchange rate regimes.

g) There should be timely, accurate and comprehensive data disclosure, including information on central bank reserves and forward operations.

In general countries which initiated the move to capital account convertibility on the basis of strong fundamentals were able to modulate the pace of capital account convertibility without dramatic changes in macro-economic policy stance. Those who went for drastic changes had to rethink, back track or in extreme case face a crisis.

\subsection{Benefits of Capital Account Liberalization}

A large number of different arguments have been advanced for capital account liberalization. Among those the important arguments are as follows:

a) Allocation arguments - "maximizing efficiency in the world's use of capital, a scarce resource" (Cooper, 1998, p.12). Capital account liberalization reduces interest rate differentials across currencies and countries, and thereby reduces international differences in the cost of capital. As a consequence, investment becomes more efficient. This argument is identical to standard arguments on the gains from free trade in goods and services.

b) Individual freedom - "individuals should be free to dispose of their income and wealth as they see fit" (Cooper, 1998, p.12). In a liberal democracy, property owners should be free to dispose of their assets as and where they wish, provided that this 
does to involve illegal activities or tax avoidance or evasion. In particular, capital market controls prevent individuals from diversifying their asset portfolios. Abolition of controls facilitates risk reduction.

c) Macroeconomic discipline - "countries stand to gain by establishing the capital markets in support of good policies" (Dornbusch, 1998, p.20). Because capital markets are forward looking, the possibility of large inward or outward capital flows imposes an element of constraint on government policies, requiring that these be feasible over the longer term. This discipline is a means for obtaining commitment to sound policies from governments which may be subject to short term electoral or other political pressures.

d) Financial market discipline - "intense capital mobility puts greater burdens on a country to ensure that its financial system is well supervised and regulated" (Dornbusch, 1998, p.20). If countries are to compete in free international capital markets, they will be required to conform to international standards with regard to reporting and to financial regulation.

e) Infeasibility - "the scope for discretionary action has become extremely limited" (Dornbusch, 1998, p.20). Capital market controls may be evaded through exploitation of special provisions and loopholes or by black or grey market operations. The net effect of controls is therefore only to increase costs. This argument contradicts those that precede it - for example, if controls are ineffective, they cannot discipline government policy and is an attempt to finesse the entire issue. We shall take it that controls are sufficiently effective for governments to wish to maintain them, since otherwise there is no point any discussion. Furthermore, the evidence from Chile and Malaysia, among other countries, demonstrates that controls can have significant effects.

f) Costs of capital account liberalization:

g) Capital account liberalization also imposes costs on developing countries - The following are among the most frequently articulated arguments against liberalization:

h) Macroeconomic Policy - Capital account liberalization complicates the conduct of macroeconomic policy, essentially by constraining the level of the domestic interest rate. This is just the counterpart of the macroeconomic discipline argument advanced as a benefit from liberalization.

i) Exchange Rate Management - Many developing countries are committed to pegged exchange rate regimes. The viability of this type of regime is underpinned by capital account controls. The Asian Crisis has shifted the majority view in the Economics profession towards a strong preference for floating rate regimes, but that transition requires a degree of central bank independence which can currently only be an aspiration in many developing countries.

j) Taxation - A characteristic of many poor developing countries is that they have a 
relatively narrow tax base. Capital market liberalization has the potential to further reduce the tax base. This is first because it is difficult to tax overseas earnings, and this makes it attractive. Secondly, there is empirical evidence that countries with capital controls tend to exhibit relatively high inflation (Dooley, 1996, p.656) resulting in lower real interest rates, and hence real service cots, on domestic debt. Capital account liberalization therefore entails either increases in explicit tax rates or reductions in government expenditure.

k) Scale of Benefits - According to Rodrik (1998), there is little econometric evidence that capital market liberalization has any effect on developing country growth.

1) Sequencing - The standard objection to capital account liberalization is that it is often premature. The direct benefits of liberalization are undisputed, but there are arguments about the appropriate sequencing of reforms. In particular, it is argued that capital account liberalization should follow, not precede, current account liberalization and should move to a flexible exchange rate regime. Our assessment of the consensus among professional economists involved in this area is that capital account liberalization is seen as providing potential net benefits, even in the poorest developing countries, but that the sequencing arguments are very important. The dominant word is therefore "Caution".

\section{Capital Account Convertibility: Issues \& Experiences of Other Countries}

\subsection{Capital Account Convertibility: Experiences of Other Countries}

In the year 1990, capital accounts were, on average, partly repressed in all regions with the exception of East Asia, where the capital accounts were already largely liberalized by then. During the 1990s, all regions showed some liberalization, but the extent differed. The following table shows the degree of Capital Account Liberalization of some selected countries in 1990 and 2003.

Table 1. Degree of capital account liberalization in 1990 and 2003

\begin{tabular}{|l|c|c|}
\hline & 1990 & 2003 \\
\hline \multicolumn{2}{|l|}{ Latin America } \\
\hline Argentina & PR & LL \\
\hline Brazil & PR & LL \\
\hline Chili & LL & LL \\
\hline Mexico & LL & LL \\
\hline Peru & PR & L \\
\hline Sub Saharan Africa \\
\hline Kenya & LL & LL \\
\hline Morocco & PR & LL \\
\hline Nigeria & PR & LL \\
\hline \multicolumn{4}{|l|}{ Uganda } & LL & L \\
\hline \multicolumn{4}{|l}{ North Africa \& Middle East } \\
\hline
\end{tabular}




\begin{tabular}{|l|c|c|}
\hline Egypt & PR & L \\
\hline Turkey & LL & LL \\
\hline South Asia \\
\hline Bangladesh & PR & PR \\
\hline India & PR & LL \\
\hline Pakistan & PR & LL \\
\hline Sri-Lanka & PR & PR \\
\hline East Asia & \multicolumn{2}{|l|}{} \\
\hline China & R & PR \\
\hline Hong Kong & L & L \\
\hline Indonesia & LL & LL \\
\hline Korea & PR & LL \\
\hline Malaysia & LL & LL \\
\hline Singapore & L & L \\
\hline Thailand & LL & LL \\
\hline
\end{tabular}

Note: Here PR: Partly repressed, R: Repressed, LL: Largely liberalized, L: Liberalized.

Source: IMF annual report on exchange arrangements and exchange restrictions, 1991 and 2003

According to IMF scores (which, of course, should be treated with caution), Latin America went the furthest towards full capital account convertibility. Sub-Saharan Africa and North Africa \& Middle-East also undertook major liberalization steps. The smallest change was observed in South Asia, a region that in 2003 was still classified as partly repressed. East Asia, while already fairly liberalized by the early 1990s, undertook modest additional liberalization.

\subsubsection{Latin American Countries}

In Latin America, Chile, Mexico and Venezuela were already largely liberalized at the beginning of the 1990s, but that contrasted strongly with all other countries, which were partly repressed, with Argentina and Peru being the most heavily repressed. This reflected the historical tradition of closed capital accounts and the debt crisis of the 1980s.

a) Argentina: Argentina adopted capital account liberalization strategy in 1991. It liberalized its capital account quite rapidly and intensively. In 1991 the adoption of the convertibility plan created a currency board. This adoption of currency board was followed by a marked increase in capital inflows in 1991-94. Foreign direct investment and portfolio inflows reached $11 \%$ of GDP in 1993, compared with less than $1 \%$ in 1990 . Argentina's access to capital market was substantially curtailed in early 1995 and there was a large outflow of short-term capital. During the first half of 1995 the central bank lost about one-third of its international reserves. The policy response to these developments did not include an imposition of capital controls. Instead the authorities adjusted macroeconomic policies including a marked tightening of fiscal policy under an IMF program adopted in March 1995. By the end of August 1995, more than half of the deposit outflows had been revised; and by December 1996 deposits had reached their precise level. 


\section{MInstitute Macrothink}

Business and Economic Research

b) Peru: Like Argentina, Peru adopted deep and fast liberalization of the capital account, from an initial position of very restrictive controls. The exchange rate was unified and a free-floating regime adopted, FDI received equivalent treatment to domestic investment, capital could be freely repatriated, non-residents could acquire domestic securities, and residents and non-residents could open foreign-currency denominated accounts, although with high reserve requirements against such accounts (Ariyoshi et al., 2000).

c) Chile: Chile (which had already largely liberalized by 1990) has been a paradigmatic case in the use of restrictions to reduce the volume of capital inflows and to influence their composition. In the early 1990s, the country experienced excessive capital inflows. To avoid excessive currency appreciation and other undesirable macroeconomic imbalances, in June 1991 the country's authorities adopted an unremunerated reserve requirement (URR) to reduce the volume of capital inflows and change their composition towards flows with longer maturity. This created a simple, non-discretionary and prudential mechanism, which penalized short-term foreign currency liabilities more heavily.

\subsubsection{East Asian Countries}

East Asian countries experienced extensive liberalization in the 1990s. However, the standard deviation in the region - IMF indicator of the degree of heterogeneity, or dispersion - both for 1990 and 2001 is the largest among all regions. This means that the regional average conceals sharp differences among the countries of the region. Four types of countries can be found in East Asia.

a) China: During 1994-97, China's international reserves increased sharply from 5.8 to 11 months of import, owing to a strong balance of payments and maintained stable exchange rate of the currency against U.S dollar. China accepted the obligations of the IMF's Article VIII in December 1996. While China was able to maintain the stability of the currency throughout the Asian crisis, capital outflows became an increasing problem in late 1997 and early 1998, driven by concerns of a devaluation of the renminbi, the falling differential between domestic and foreign interest rates, and increasing circumvention. The current account remained in surplus and foreign direct investment remained strong, but the capital account deteriorated sharply. As a result overall balance of payments surplus fell sharply, from $\$ 36$ billion in 1997 to $\$ 6$ billion in 1998. In response to these developments, the authorities significantly intensified enforcement of exchange and capital controls and moved to reduce circumvention. These measures involved enhanced screening of capital account transactions and increased documentation and verification requirements on current transactions. The measures were implemented with a view to safeguard illegal capital outflows and ultimately maintaining a stable exchange rate. These steps improved the BOP situation of China. Now in China FDI allowed but volume above $\$ 1$ million requires signing contract with government. There are ceilings and minimum holding periods. Effective from April 2001, all controls on outward FDI were abolished. Nonresident 
may freely purchase local shares subject to a minimum holding period. Residents are also permitted to purchase portfolio securities from abroad. Credit operations are controlled.

b) South Korea: Korea is the country that, started from an initial fairly restrictive position, undertook the largest capital account liberalization during the decade to reach a fairly open stance by 2001 . The country started out gradually, with residents being permitted to issue securities in abroad and foreigners being allowed to invest directly in the Korean stock market (though limits existed on the latter). From 1993 until 1997, the process was accelerated with the lifting of barriers on short-term borrowing to different sorts of domestic activities previously restricted, investment by non-residents in public bonds, and permission to issue equity-linked bonds and non-guaranteed bonds by small and medium-sized firms, and non-guaranteed long-term bonds by large firms.

Some restrictions were maintained, however, particularly on some forms of capital inflows, due to concerns about surge of capital inflows, caused by interest rate differentials. These were mainly in the form of ceilings on foreign investment in domestic equity securities and borrowing from abroad by non-banks. However, the exceptions to these, which proved harmful, included the liberalization of trade related short-term financing to domestic firms and short-term foreign currency borrowing by domestic banks (Shin and Wang, 1999).

c) Malaysia: Malaysia has been relatively open for years, and experienced a massive surge of capital inflows in the early 1990s. Until then, the limits on capital inflows consisted mainly of ceilings on foreign currency borrowing, beyond which approval was required. To further limit such flows, especially short-term ones, in 1994 the authorities prohibited the selling by residents to non-residents of money market securities, and commercial banks were forbidden to engage in swap and forward contracts with non-residents. Ceilings were imposed on banks' net foreign exchange open positions, and reserve requirements were decreed for foreign currency liabilities of commercial banks. Most of these controls were subsequently lifted, with only the prudential ones remaining in place. The assessment of Ariyoshi et al. (2000) is that such controls were effective both in reducing the volume and changing the maturity of flows. During 1997 and early 1998 Malaysia suffered massive capital outflows. In response to that, in September 1998 the country's authorities adopted a number of restrictions on capital outflows. These included: prohibition of using domestic currency in trade payments and offshore trading, prohibition of credit facilities between residents and non-residents, and repatriation of non-resident portfolio capital, which was blocked for 12 months (Ariyoshi et al. 2000). Controls were later relaxed and then totally eliminated. Residents are now permitted to obtain financial credit facilities in foreign currency up to the equivalent of RM 5 million. But investment abroad exceeding RM 10000 in any form requires approval.

d) Thailand: Thailand's liberalization was the most aggressive during the 1990s, 
particularly in the early 1990s with the creation of the Bangkok International Banking Facility (BIBF), which through tax privileges greatly encouraged external flows, especially short-term ones (Johnston et al., 1997). Outflow of capital exceeding \$10 million a year required approval. Foreign capital may be brought into the country without restriction. Because of rapid capital account liberalization Thai baht came under severe speculative pressure in May 1995. So, in 1995, restrictions were imposed to reduce the volume of (mainly short-term) capital inflows, which became excessive in the first half of the 1990s. These restrictions included a 7 percent reserve requirement on non-resident accounts with a maturity of less than one year and on short-term borrowing of finance companies; limits for open short and long foreign currency positions (with lower limits for short positions); and reporting requirements by banks on risk control measures regarding foreign exchange and derivatives (Ariyoshi et al., 2000). However, capital continued to flow in large amounts by taking different forms (Siamwalla, Vajragupta and Vichyanond, 2003). In response to that, in 1996 the reserve requirements were extended to short-term borrowing by commercial and BIBF banks. According to Ariyoshi et al. (2000), such controls on capital inflows succeeded in reducing the volume of inflows, lengthening their maturity, reducing the short-term debt to total debt ratio, and reducing the growth of non-resident baht accounts. However, these developments were not sufficient to avoid the reversal of capital flows the country experienced in 1997. Now in Thailand non-residents are allowed to purchase portfolio capital locally, but purchase or issue abroad requires approval. Same rule apply for money market instruments. Authorized banks are allowed to grant loans up to $\$ 10$ million.

e) Indonesia: Indonesia greatly encouraged capital flows, especially FDI, from the start of the decade. Bank lending to the domestic corporate sector also became prominent in the 1990s. In the mid-1990s, there was an effort to prioritize FDI over other types of flows, with ceilings on foreign lending being used as an instrument, but with poor effectiveness (Gottschalk and Griffith-Jones, 2003).

Finally, Hong Kong and Singapore are among the few developing countries with almost totally liberalized capital accounts as early as 1990. Both countries remained open, though a few restrictions are in place. For example, in Hong Kong, the disclosure and position limits on derivative products are required, in addition to prudential limits on open foreign exchange positions and on certain forms of capital outflows. In the case of Singapore, there are upper limits for foreign lending from residents to non-residents in Singapore dollars, and an obligation for non-residents to convert proceeds in Singapore dollars into foreign currency. These measures are aimed at discouraging the international use of the domestic currency. Also, there are certain prudential limits and restrictions on capital outflows.

\subsubsection{South Asian Countries}

South Asian countries have adopted a cautious approach to capital account liberalization. Liberalization of capital account transaction should be undertaken from a relatively strong 
balance of payments position. As the balance of payment position of south Asian countries are not so good, so they have taken cautious approach to capital account liberalization.

- India: Since the external crisis of 1991, India has undertaken economic reforms, including partial capital account liberalization, to begin reversing several decades of inward-looking and interventionist policies. FDI was liberalized first in India. Portfolio equity flows were selectively liberalized during the 1990s, and the liberalization of external borrowing was very limited. The country relied extensively on quantitative and other controls. These included overall quantitative ceilings, approvals on a case-by-case basis, different degrees of restrictions according to the maturity of foreign liabilities, and end-use restrictions. Strong limits were imposed on short-term debt. In June 1997 - thus just before the East Asian crisis broke out - the Tarapore Committee recommended a timetable for further capital account liberalization in India (Reserve Bank of India, 2000). The proposed liberalization included both capital inflows and outflows; liberalization was to be progressive, in three phases, over three years. However, these liberalization steps were conditional on the country meeting certain pre-conditions. By 2001, India's capital account was still only partially liberalized, with strong restrictions remaining in place, particularly on capital outflows by residents. Apparently due to this more cautious approach, and to its high level of foreign reserves, the country managed to escape the financial crises of the 1990s and even to avoid contagion effects during the East Asian crisis. With the reorientation of capital account policy toward non-debt-creating inflows and foreign direct investment external indebtedness has declined markedly. However, there are indications that India's wide-ranging capital and other economic controls may have reduced economic growth compared with other Asian economies with a more open economic system.

- Pakistan: Alongside India, Pakistan is the other South Asian country that pursued significant liberalization steps during the 1990s. In fact it went further than India, with most types of capital inflow liberalized. Most of the remaining restrictions are on capital outflows by residents, though lately some initial steps have been taken to liberalize outflows.

- Sri Lanka: Although having undertaken some liberalization steps, the capital account in Sri Lanka remains quite repressed. These two countries have maintained capital restrictions in the form of outright prohibitions (for example in the case of money market instruments and derivatives) and central bank approval (for example for long-term borrowing). Capital outflows by residents are still strongly restricted.

\subsubsection{Sub Saharan Africa}

a) Kenya: Kenya was another fast liberalizing country in the region. In a context of shortage of foreign reserves and large fiscal deficit, in 1991 the country embarked on a program of reforms that included rapid current and capital account liberalization. The Capital Account liberalization included permission to hold foreign currency certificates of deposit, which could be traded by residents and non-residents, used for 
any foreign exchange transaction, and reclaimed at the Central Bank at face value. In addition, some companies could hold foreign currency denominated bank accounts abroad and domestically (Ayiroshyi et al, 2000). In 1994, the domestic currency became fully convertible, and in 1995 most of the remaining controls on foreign exchange transactions were removed (including access by foreigners to shares and government securities). Among the few exceptions, foreigners could hold portfolio equities up to $5 \%$ individually and $40 \%$ in aggregate. The overall result of capital account liberalization in Kenya in the context of broader reforms was macroeconomic volatility and increased capital flight (Ayiroshyi et al., 2000).

\section{Current Account Convertibility in Bangladesh}

\subsection{Convertibility of Taka}

Convertibility is the ability of the owner of the asset (foreign currency and foreign exchange) to exchange it from one currency to another. Convertibility assures that every holder of the currency is able to obtain at the margin an equal satisfaction from it as he could obtain from other currencies. A currency is said to be convertible when it may be fully convertible for another currency. Convertibility of currency is not for domestic transactions, it is only required for international transactions.

On 20th October, 1993 Bangladesh Taka has been declared convertible on current account transactions and on the 11th April, 1994 Bangladesh government has been awarded with the Article VIII status of International Monetary Fund (IMF) Articles of Agreement. The declaration means a commitment on the part of Bangladesh to allow her citizens to convert the Taka into foreign exchange to meet obligations falling into the category of current account. The declaration did not come about all on a sudden. Preparations for convertibility started a long time back in the seventies. Since 1976, a lot of economic reform measures were under taken in Bangladesh. These reform measures include: denationalization and privatizations of industries and bank, improvement of fiscal management, tariff rationalization, opening of trade regime etc. these has paved the road of convertibility.

Sequencing of reform measures is very important for the matter of achieving desired result for an economy. Real sector reform and financial sector reform should go hand in hand. Internal financial liberalization should be accomplished before external financial liberalization is undertaken. Some east European countries could not achieve desired results due to improper sequencing of reform measures. Bangladesh has followed the correct path in terms of sequencing the various reform measures. Foreign exchange reform or Taka convertibility on current account has been implemented as the last in the chain of various reform measures. We have not made our currency convertible on capital account yet.

Convertibility of Taka has produced mixed results. Foreign investment both direct and portfolio types have risen. Relaxation of exchange controls by Bangladesh bank on remittance of profit and dividends to foreign investors have provided incentives to the foreign direct and portfolio investors to invest more funds. It may be expected that as Taka is getting international status and currency management system has improved the foreign private investment as well as 
the overall investment level will improve soon. Another great advantage that has been visible after Taka convertibility is the removal of "chilling effect" arises out of unnecessary delay in making a transaction. Now people can complete their transactions within shortest possible time. On the other hand convertibility of Taka coupled with low interest rates push the rate of growth of imports upward.

Convertibility is not the only engine of growth. It just creates a positive environment to foreign investment, greater flexibility to recognize production techniques with easy access to advanced technology. Other economic and non-economic should also be considered for determining the impact of convertibility. For a rapid and balanced development of the economy we need to do much more than conversation. We need to formulate appropriate fiscal, monetary and other policies having being on the country's productive capabilities. We must improve our managerial and entrepreneurial capabilities, produce good labor force and remove bureaucratic bottlenecks; otherwise expected results cannot be achieved.

\subsection{Foreign Exchange Regulation Act, 1947 and Deregulatory Measures}

Bangladesh Bank issues licenses to deal in foreign exchange empowered by the foreign exchange regulation act 1947. Central bank may issue general licenses or licenses with authority to perform limited functions only. The authorized dealers must maintain adequate and proper records of all foreign exchange transactions and furnish such particulars in the prescribed returns for submission to the Bangladesh Bank. They should report to Bangladesh bank in regard to any attempt of the provisions of the Act.

Since 1976 a lot of reform measures have been undertaken in Bangladesh. The major deregulatory measures and changes taken place during last few years have been pointed out in the following paragraphs.

- Bangladesh bank in exercise of the powers conferred by the Foreign Exchange Regulations Act, 47 issues licenses to commercial banks to deal in foreign exchanges. The central bank has also permitted a number of Moneychangers to exchange cash foreign currency notes, coins or foreign currency instruments such as traveler's cheques.

- With the exceptions of few reform sectors, foreign investors are free to make investments in Bangladesh in industrial enterprises Local residents are free to invest in shares/securities, with foreign exchange sent or brought in to Bangladesh. Foreign investors are free to remit their post-tax profits and dividend on their own countries.

- Foreign owned as well as joint venture industrial units located in Bangladesh may freely borrow funds in foreign currency from aboard. Local banks may extend working capital loans or term loans in local currency to foreign controlled or foreign owned firms operating in Bangladesh.

- Annual foreign exchange quota for business travel aboard for the new exporters has been set as US \$ 6000. Merchandise exporters may retain 25\% of realized FOB value of their exports in foreign currency accounts. 


\section{I Macrothink}

Business and Economic Research ISSN 2162-4860 2014, Vol. 4, No. 1

- Incoming passengers may be in any amount of foreign exchange with declaration in FMJ form at the time of arrival. No declaration is necessary for amount up to US\$ 5000.

- Non-resident foreign currency deposit (NFCD) accounts may now be maintaining as long as the account holder desire.

- Persons ordinarily in Bangladesh may maintain foreign currency accounts with foreign exchange brought in at the time of their return to Bangladesh from visits aboard. These accounts are termed as Resident Foreign Currency Deposit (RFCD) accounts.

- Bangladesh nationals having bank accounts aboard which were opened while working there may now maintain such accounts even after their return to Bangladesh.

- Travel quota entitlement of Bangladesh nationals is set at US\$3000 per year for visits to countries other than SAARC member countries and Myanmar. For SAARC member countries and Myanmar it is US\$ 1000 for travel by air and US\$ 500 for travel by land route.

- A Bangladeshi national returning from aboard may bring in to Bangladesh up to 10 kilograms of gold or 20 kilograms of silver in bullion/ingot from subject to payment duties and taxes as levied by the government.

- Education sector was declared fully convertible. Prior permission of Bangladesh bank is not required for releasing foreign in favor of Bangladesh students studying aboard or willing to proceed aboard for studies.

- Authorized dealers may release foreign exchange up to US\$10,000 for medical treatment aboard on the basis of recommendation of Medical Board constituted by the Health directorate and cost estimate from the foreign medical institutions.

- Remittance of moderate amounts of foreign exchange of family maintenance aboard of Bangladesh nationals are allowed by Bangladesh bank on written request supported by certificate from the Bangladesh mission in the concerned country.

- Bangladesh bank has stopped sales and purchases with Authorized Dealers of any currency other than the US Dollar; to encourage the Authorized Dealers to buy and sell other currencies in the inter bank market.

- To encourage authorized dealers to avoid frequent transactions with central bank and instead to resort to inter bank deals, Bangladesh bank has raised its transaction there hold to US\$ 50,000. Bangladesh bank has also left the Authorized Dealers free to quote their own rates for inter-bank transactions and transactions with non-bank customers.

- Bangladesh Foreign Exchange Dealers Association (BAFEDA) has been formed and a "Code of Conduct" for treasury operations and interbank foreign exchange market has been formulated. 


\section{External Financial Integration of Bangladesh}

\subsection{Balance of Payment Analysis}

International business is facilitated by markets that allow for the flow of funds between countries. The transactions that arise from international business cause money flow from one country to another. The balance of payments represents a measure of international money flows. Balance of payment account records the international economic transactions of a country with the rest of the world during a particular period of time.

Table 2. Presentation of Balance of Payment (BOP), 2000-2004 (millions of us dollars)

\begin{tabular}{|c|c|c|c|c|c|}
\hline ITEMS & 2000 & 2001 & 2002 & 2003 & $2004 *$ \\
\hline Trade balance & -1865 & -2011 & -1768 & -2215 & -2319 \\
\hline Export fob(including EPZ) & 5701 & 6419 & 5929 & 6492 & 7521 \\
\hline Of which RMG & 4352 & 4860 & 4584 & 4912 & 5686 \\
\hline Import fob (including EPZ) & -7566 & -8430 & -7697 & -8707 & -9840 \\
\hline Services & -645 & -914 & -499 & -691 & -874 \\
\hline Receipts & 849 & 759 & 865 & 887 & 924 \\
\hline Payments & -1494 & -1673 & -1364 & -1578 & -1798 \\
\hline Income & -302 & -344 & -402 & -358 & -374 \\
\hline Receipts & 97 & 97 & 50 & 64 & 63 \\
\hline Payments & -399 & -441 & -452 & -422 & -437 \\
\hline Of which, official interest payments & -160 & -168 & -161 & -167 & -175 \\
\hline Current Transfers & 2394 & 2171 & 2826 & 3440 & 3743 \\
\hline Official & 165 & 72 & 69 & 82 & 61 \\
\hline Private & 2229 & 2099 & 2757 & 3358 & 3682 \\
\hline Of, which workers Remittances & 1949 & 1882 & 2501 & 3062 & 3372 \\
\hline Current Account Balance & -418 & -1098 & 157 & 176 & 176 \\
\hline Capital Account & 561 & 432 & 410 & 428 & 196 \\
\hline Capital Transfers & 561 & 432 & 410 & 428 & 196 \\
\hline \multirow{2}{*}{\multicolumn{6}{|c|}{ Financial Account }} \\
\hline & & & & & \\
\hline Foreign direct investment & 383 & 550 & 391 & 376 & 385 \\
\hline Portfolio investment & 0 & 0 & -6 & 2 & 6 \\
\hline Other investment & -499 & 132 & 6 & 35 & -313 \\
\hline MLT loans & 806 & 790 & 733 & 918 & 544 \\
\hline MLT amortization payments & -396 & -416 & -435 & -452 & -397 \\
\hline Other long term loans (net) & 127 & -13 & -42 & -20 & -41 \\
\hline Other short term loans (net) & 71 & 31 & 63 & 142 & 13 \\
\hline Other capital & -190 & -114 & -87 & -125 & -125 \\
\hline Trade credit (net) & -641 & -260 & -253 & -499 & -321 \\
\hline Commercial Bank & -276 & 114 & 27 & 71 & 14 \\
\hline Assets & -161 & 1478 & -90 & 217 & 86 \\
\hline
\end{tabular}


$*$ = Provisional

Source: Annual Report (2003-2004) of Bangladesh Bank

The table 2 shows that in the year 2000 and 2001 the country has experienced a deficit in its current account balance but after 2001 to onward the country has experienced a surplus in its current account balance. After 1998 there was instability in political situation that continued up to 2001 due to political unrest. Also Bangladesh experienced natural disaster in 2000, so in the year 2001 there was huge deficit in current account balance. Other component of the current account such as services and income account shows negative balance but the current transfer shows positive balance only. The balance in current transfer is increasing at an increasing rate.

a) Trade: Export is increasing but at the same time import is increasing that's why there always exists a negative trade balance.

b) Services: there is negative trend that means deficit in the services account and ups and down trend.

c) Income: there are fluctuations in income account from 2000 to 2004.

d) Remittance: There is a positive trend in remittance coming to the country. In the year 2000 and 2001 the worker's remittance coming to the country was lower. But the situation improved from year 2002.

e) Capital account: Capital account is not convertible in Bangladesh but in year 1992-93 and 1998 experienced deficit balance. In year 2004 capital transfer has substantially decreased. On the other hand the experience of capital account liberalization in the developing countries has varied across countries, reflecting their different degrees of macroeconomic imbalances and BOP strength and the extent of general economic liberalization. Prior to mid 1980's liberalization of capital account transactions has been undertaken in a number of countries having relatively strong BOP position (Indonesia, Malaysia and Singapore) but recently a number of developing countries adopted full convertibility following the BOP deficits (Mauritius, Trinidad and Tobago).

f) Foreign direct investment: The table shows that foreign direct investment in our country increased at an increasing rate. But there is a very little portfolio investment in our country. Reserve assets have shown deficit balance in all the year from 2000 to 2004 except in the year 2001. 


\subsection{External Financial Integration and Economic Growth}

It is obvious that the relationship of financial integration and economic growth is not so direct and simple. Financial integration and external capital flows are said to be typically associated with some features of the economy like investments, savings, productivity, and financial development that contribute in economic growth.

Based on theoretical review, some macroeconomic variables are compared in pre (1991-1996) and post openness period (1997-2002). To have a distinctive picture between pre-openness and post-openness period, a dummy variable model $(y=\partial 0+\partial 1 \mathrm{Di}+\mathrm{U}$, Where $\mathrm{D}=0$ for pre openness period and $D=1$ for post openness period), and growth model (in $Y=\beta 0+\beta t+U$ ) are estimated using Bangladesh data (Ahsan Habib, 2004, p.14). For estimating growth model the period 1991-1997 and 1997-2003 are used as pre and post openness period to have greater degree of freedom.

As the estimated results (table-5.2) show, there were positive changes in the level of GDP growth rate and per capita GDP rate (annual average) in the post openness period as compared to pre openness period. Annual average level of real GDP and per capita GDP increased from 4.77\% and TK. 12416 respectively during 1991-96 to about 5.20\% and TK. 19130 during 1997-03. In both the periods, per capita GDP registered annual average growth of about $7 \%$ (Appendix-5). There was however negative annual average change in the GDP growth (\%) in the post openness period (Table-5.3).

Table 3. Mean differences in the selected indicators during pre-openness (1991-96) and post-openness (1997-03) period.

\begin{tabular}{|l|c|c|c|}
\hline \multicolumn{1}{|c|}{ Variables } & $\partial_{0}$ & $\partial 1$ & $\mathrm{t}$ \\
\hline GDP Growth (\%) & 4.77 & .400 & 1.47 \\
\hline PCGDP (TK.) & 12416.33 & 6714.2 & 5.76 \\
\hline GDS to GDP (\%) & 13.83 & 4.06 & 7.45 \\
\hline GDI to GDP (\%) & 18.90 & 3.80 & 6.45 \\
\hline GFCF to GDP (\%) & 16.83 & 3.64 & 6.08 \\
\hline Broad money to GDP & 26.55 & 6.03 & 3.56 \\
\hline Private credit to GDP (\%) & 17.00 & 5.67 & 4.52 \\
\hline Ratio of GDP to Total investment & 5.30 & -0.90 & -5.80 \\
\hline
\end{tabular}

Note: Abbreviations used: PCGDP- Per capita GDP; GFCF- Gross fixed capital formation at market price; GDS- Gross domestic savings; GDI- Gross domestic investment.

Source: Estimations are based on Bangladesh bank and GOB data.

Table 4. Average growth of the selected indicators in Pre and Post openness period

\begin{tabular}{|l|c|c|}
\hline \multicolumn{1}{|c|}{ Indicators } & $1991-1996$ & $1997-2003$ \\
\hline GDP Growth (\%) & .0964 & -0.053 \\
\hline GDS to GDP $(\%)$ & .6893 & 0.3143 \\
\hline GDI to GDP $(\%)$ & .7179 & 0.4070 \\
\hline GFCF to GDP $(\%)$ & .4994 & 0.5288 \\
\hline
\end{tabular}




\begin{tabular}{|l|c|c|}
\hline Broad money to GDP & .6571 & 1.730 \\
\hline Private credit to GDP (\%) & .9690 & 1.089 \\
\hline Ratio of GDP to Total investment & -0.1926 & -0.0832 \\
\hline
\end{tabular}

Source: Estimations are based on Bangladesh Bank and GOB data.

Both savings and investment rates (to the GDP) attained statistically significant improvement in the post openness period as compared to the pre openness period (Table-3). However, the level of savings and investment rates of Bangladesh remained low ( were only $18.2 \%$ and $23.2 \%$ of GDP in 2002 respectively) in global perspective. It can be observed (from table-5.3) that the rate of change of the variables (savings and investment as \% of GDP) decelerated during 1997-2003, and total investment of the country increased (\%) at slower pace in the period compared to the pre openness period (Appendix-1). Though marginally, it is a positive sign that domestic long term investments (GFCF to GDP) registered better rate of change in the post openness period (table-5.3).

Both the financial deepening indicators (broad money to GDP and private credit to GDP) attained statistically significant changes between pre and post openness period. Broad money and private credit (to GDP) increased from $26 \%$ and $17 \%$ to about $32 \%$ and $22 \%$ respectively (Table-5.2). Especially, growth rates of broad money registered significant improvement over the period 1997-03 and the level reached to about 37\% (of GDP) in the year 2003 (BB data). As the Appendix-5 indicates, except broad money, other variables (private credit, total investment, and gross fixed capital formation) experienced lower annual average percentage growth during the post openness period.

\subsection{Absorption of External Capital Inflows and Growth}

The evidences (Appendix-2) suggest that there were notable differences in the composition of absorption of capital inflows in the selected countries. The countries like Chile, Indonesia, Malaysia, and Thailand reduced share of consumption in GDP during the inflow period (Appendix-2). Positive development has taken place in Bangladesh in connection with the composition of absorption of capital flows. The country registered slow improvement in the average level of investment to GDP ratio during the inflow period as compared to the immediately preceding period of equal length. Consumption to GDP ratio decreased and current account of the economy found improvement during the inflow period 1997-2003 (Appendix-3). However, investment level of the country remained low, and consumption remained at considerably higher level in global context (Appendix-3).

\subsection{Current Account, Export Growth and Foreign Exchange Reserve}

The levels of current account deficits of Bangladesh were clustering around 1\% of GDP toward the end of 1990s that became positive in 2001 and improved in the following year. Bangladesh's balance of payment (BOP) stability and international reserve largely depend on export earnings. The country's exports of goods and services (to the GDP) increased by about 9\% over 1990s, but it remained in the category of low exporting countries (Appendix-4). Though capital account appeared to be the main force in pulling up foreign exchange reserves in many economies (as in India), the impact of increase in FDI flows to Bangladesh's reserves 
has been limited.

In this age of financial globalization, it is much more popular to assess reserves position in terms of short term capital. In this regard Bangladesh is clearly out of danger having restrictions on short term debt and with its limited portfolio capital flows. However, still it was lower than 3 months of imports of the country as of June 2003.

\section{Conclusion and Recommendation}

\subsection{Conclusions}

Opening of the trade and financial sector is becoming a compelling reality for the developing countries. Opening of external sector is necessary for the countries that wish to take benefit of the open world economic system by raising investment and foster economic growth. Empirical study (Klein and Olivie, 99) shows that opening of financial sector increases the growth and financial depth of a country. Convertibility of Taka in current account is a necessary step in this openness process.

New reform measures have already been taken to boost export and attract foreign investment. Foreign investors in Bangladesh are already got a package of facilities including tax holiday, profit remittance, EPZ and other facilities. This reform resulted in higher foreign investment and international trade. But the growth of foreign investment is not significant yet comparing to the neighboring countries.

Bangladesh Taka is already awarded IMF Status of Article VIII in 1994. This is one of the major financial reform measures country has taken so far. It effected positively to the international trade also. Deregulation of exchange rate determination is another significant reform measure taken by Bangladesh. Now the market forces determine the exchange rate of Taka. This step is vital for improving the foreign exchange market in Bangladesh, especially when the country is lagged behind the terms of well functioning money and capital market. By deregulating the exchange rate, the country moved further towards financial liberalization.

Balance of payment (BOP) situation is one of the vital factors regarding a country's involvement in international trade. The BOP of Bangladesh showed, generally, a deficit tendency in its trade and current account balances. A relatively weaker BOP may create financial crisis if the country opens up its capital account. The Asian crisis in 1996 also suggests that countries with BOP problems suffered most at that time. Thus before opening the capital account, Bangladesh first is required to improve its macro economic accounts especially BOP position.

Now a day's one country cannot open its trade sector without going for convertibility. Convertibility is positively related with country's international trade and the financial deepness (Klein and Olivei, 1999). So, Bangladesh has to integrate trade and financial liberalization measures effectively and orderly to achieve benefits from it.

The overall economy of Bangladesh suggested that the country has to improve its macro-economic accounts further in order to make Taka convertible on capital account transactions. Today FDI has contributed significantly less to net resource flow to Bangladesh 
than that of the most of the developing countries of Asia and there is still substantial scope to improve the sustainability of external financing in Bangladesh. It is very important in the context of Bangladesh as its capital market is underdeveloped. FDI provides far more than just capital, it provides benefits in the form of managerial know how and modern technology. Moreover, at the current economic condition in Bangladesh, higher growth rate can be achieved by supplementing the countries lower domestic saving by foreign capital inflows. FDI has typically proven to be least volatile item and a strong resilience of FDI reduces the risk of contagion. Therefore, the country should aim at higher level of FDI in external financing which is clearly very low in Bangladesh.

However, experience suggests that capital outflow has to be permitted to increase the net inflows in the long run, because controls on outflows effectively reduce inflows also. Moreover, high inflow of capital has not always proved to be a positive factor in the economic growth. Its destabilizing side effects in the form of rise in inflation, adverse effect on the competitiveness of the export industries must be minimized by effective stabilization policy to get the positive contribution of higher level of inflows. Thus, relaxing control on capital outflows (permitting local institutions to make investments aboard, allowing on domestic entity to issue local currency bonds in domestic market etc.) would be necessary to stabilize capital inflows in near future in Bangladesh. However, the most important point to be noted that, only removal of restrictions from outflow of capital would rather make the situation worse if supportive measures are not ensured. Steps must be taken with regard to the weakness of financial institutions, inadequate infrastructural facilities, and corruption in the bureaucratic system, inadequate legal system and political confrontation that are very important factors for the confidence of foreign investors.

\subsection{Recommendations}

For the strategies to harmonize the liberalization of external sector and financial system and also keeping in mind the present economic performance of Bangladesh, the following issues may be considered:

1. There is no alternative way for Bangladesh but to open up the trade and financial sector. So, before liberalizing the country must prepare her for the associated opportunities and risks of openness. The authority should cross-examined, thoroughly, the liberalization issues before taking further steps.

2. In moving towards capital account convertibility financial sector vulnerability is probably the most serious concern for Bangladesh. Some prudential measures have been adopted in recent days; however, only strict execution and application of the adopted policies would provide accepted result.

3. Bangladesh's tiny stock market and government bond market need a big push for effective monetary policy operation. Moreover, it is crucial to have cooperation from fiscal authorities in adopting effective monetary policy.

4. Based on experiences of other countries, it is now widely accepted that external financial liberalization should follow internal financial liberalization (Choudhury and 
Raihan, 1999) and Bangladesh is no exception to it.

5. The aim of internal liberalization of Bangladesh is to attain higher growth and stability on its macro-economic factors. The already fragile banking sector should need further attention regarding solvency and non-performing assets.

6. Steps must be taken to attract more foreign investment by taking the appropriate measures with regard to the weakness of financial institutions, inadequate infrastructure facilities, corruption and red-tapism in the bureaucratic systems, inadequate legal system and political unrest in the country.

7. At present Bangladesh needs the type of FDI that will have significant impact on incremental exports in order to offset rising payment liabilities overtime and to pull up foreign exchange reserves.

8. Macroeconomic conditions of the country need to be improved to safeguard the economy from plunging in to instability. Sufficient foreign exchange reserve should be ensured, fiscal deficit should be brought down to a reasonable level, lower rate of inflation should be maintained and ensuring political stability are required with regard to the non-performing advances of banks. The contractionary policy, (very high level of statutory reserve requirements to limit the credit) may not be a good option in the presence of a number of problem banks in the economy. With regard to the recovery drive of the defaulted loan the result is impressive, but the speed is slower. More emphasis should be given with regard to the recovery of the defaulted loan and the screening procedure should be strengthened to sanction new loans.

9. Some sort of control over the capital mobility is necessary to safeguard financial crisis. In this regard the country could manage the asset, liability and duration management accordingly.

10. Making Taka convertible on capital account transactions does not necessarily mean full removal of restrictions on capital mobility. The country should have some control over capital mobility to protect the crisis.

If the government in able to develop their policies and implement them properly then the real investors will come to Bangladesh, with capital and technology, and then actual financial development will take place that will lead to overall economic growth.

\section{References}

Alam, Khorshed. (1995). Convertibility of Taka for Current Transactions in Bangladesh. Bangladesh Bank, Dhaka.

Ariyoshi, A. et al. (2000). Capital Controls: Country Experiences with Their Use and Liberalization. IMF Occasional Paper No. 190.

Bangladesh Bank. (1996-2003). Bangladesh Bank Bulletin, Dhaka.

Bangladesh Bank. (2004). Annual Report 2003-2004 . Dhaka. 
Bangladesh Bank. (2005). Economic Trends . Dhaka.

Bangladesh Bureau of Statistics, Foreign Trade Statistics . Dhaka, 1994-95 to 1998-99.

Bangladesh Bureau of Statistics. Statistical Yearbook of Bangladesh, Dhaka . 1991-92 to 1999-2000.

Chaudhuri, B. K. (1988). Finance of Foreign Trade And Foreign Exchange . Himalaya Publishing House, Bombay.

Choudhury, T. A. (2002). Reading Materials on International Finance (Compiled). BIBM, Dhaka.

Choudhury, T. A., \& A. Raihan. June, (1999). Implications of WTO on the Banking and Financial Sector in Bangladesh. Bank Parikrama, BIBM, Volume XVIV, No. 1.

Choudhury, T. A., \& Mahmudul A. Masud. (2002). Reading Materials on International Trade And Finance (Compiled). BIBM, Dhaka, 2002.

Choudhury, T. A. (1993). Convertibility of Currency: Conceptual Framework and Requirements. A Paper Presented in a Workshop Organized by Independent University, Dhaka.

Choudhury, Toufic Ahmad, \& Ananya Raihan. Globalization and Finance for Development. Published in Bangladesh Facing the Challenges of Globalization: A Review of Bangladesh's Development 2001, The Centre for Policy Dialogue and The University Press Limited, Dhaka, 2002.

Cooper, R. (1998). Should Capital-Account Convertibility be a World Objective?, in Should the IMF Pursue Capital-Account Convertibility, Essays in International Finance, 207, Princeton University.

Cooper, R. (1999). Should Capital Controls be Banished? . in Brookings Papers on Economic Activity, 1, pp. 89-141. http://dx.doi.org/10.2307/2534663

Dooley, M. P. (1996). A Survey of the Literature on Controls on International Capital Transactions, IMF Staff Papers, 43, 639-87. http://dx.doi.org/10.2307/3867365

Dornbusch, R. (1998). Capital Controls: An Idea Whose Time is Past', in Should the IMF Pursue Capital-Account Convertibility, Essays in International Finance, 207, Princeton University.

Eichengreen, Barry, \& Michael Mussa. (1998). Capital Account Liberalization and the IMF'. in Capital Account Liberalization: Theoretical and Practical Aspects . IMF Occasional Paper 172, Washington DC, December.

Fischer, S. (1998). Capital Account Liberalization and the Role of the IMF' in Should the IMF Pursue Capital-Account Convertibility?, Essays in International Finance, 207, Princeton University.

Griffith-Jones, S., Gottschalk, R., \& Cirera, X. (2003). The OECD Experience with Capital Account Liberalisation. UNCTAD. forthcoming. 
Habib, Shah, Md. Ahsan, Dr. Khondakar G. Moazzem. (2004). Implications of Financial Globalization for Bangladesh . BIBM. Dhaka.

Hassan, M. Kabir. (1998). The Asian Financial Crisis and the Bangladesh Economy. Bank Parikrama, BIBM, Vol. XXIII, March \& June.

IMF. (2002). IMF-Supported Programs in Capital Account Crisis . Washington DC.

International Monetary Fund. (2002). Exchange Arrangements And Exchange Restrictions. Annual Report, Washington DC.

International Monitory Fund. (2003). Liberalization of Capital Account- Experiences and issues . Occasional Paper, Washington D C.

International Monitory Fund. (2005). International Financial Statistics Yearbook . Washington D C.

Islam Muinul, et al. Bank Loan Default Problem in Bangladesh: A Dialogue Between Borrowers and Lenders. Bank Parikrama, BIBM, Vol. XXIV, No. 2, June, 1999.

Johnston, B., Darbar. S., \& Echeverria, C. (1997). Sequencing capital account liberalisation : lessons from the experiences in Chile, Indonesia, Korea and Thailand, IMF Working Paper, WP/97/157, November.

King, R. G., \& R. Levine. (1993). Finance, Entrepreneurship and Growth, Journal of Monetary Economics, 32, 523-42. http://dx.doi.org/10.1016/0304-3932(93)90028-E

Klein M., \& G. Olivei. (1999). Capital Account Liberalization, Financial Depth, and Economic Growth . NBER, Cambridge.

Lall. Sanjana. (1993). Foreign Direct Investment In South Asia. Asian Development Review, Voll-II.No. 1, ADB, Manila.

Mahmud, Kalam. (1999). Convertibility and Globalization: A Case Study of Bangladesh . MBM Dissertation, BIBM.

Mahmud, W. (1998). Macroeconomic Management And Reforms: Issues In Governance. Crisis in Governance- A Review of Bangladesh Development 1997, Dhaka. CPD \& UPL.

Mckinnon, Ronald I. (1979). Money in International Exchange: The Convertible Currency System . Oxford University Press, Oxford.

Ministry of Finance. Bangladesh Economic Review. Dhaka, 1996-2002.

Rao, M. J. Manohor. (1997). Macroeconomics of Capital Account Convertibility. Economic And Political Weekly, India.

Rodrik, D. (1998). Who Needs Capital-Account Convertibility? in Should the IMF Pursue Capital-Account Convertibility, Essays in International Finance, 207, Princeton University.

Shin, I., \&Wang, Y. (1999). How to Sequence Capital Market Liberalisation: Lessons from the Korean Experience . KIEP Working Paper 99-30, Seoul. 


\section{Macrothink}

Business and Economic Research

ISSN 2162-4860 2014, Vol. 4, No. 1

Siamwalla, A., Vajragupta, Y., \& Vichyanond, P. (2003). Foreign Capital Flows to Thailand: Determinants and Impact, University of Michigan Press, Ann Arbor.

Siddiqui, Ziaul H. (1993). Impact of Convertibility. A Paper Presented in a Workshop Organized by Independent University . Dhaka.

World Bank. (2005). World Development Indicators . Washington D C.

\section{Copyright Disclaimer}

Copyright reserved by the author(s).

This article is an open-access article distributed under the terms and conditions of the Creative Commons Attribution license (http://creativecommons.org/licenses/by/3.0/). 